- DOI: $10.31866 / 2410-1311.35 .2019 .188820$

УДК 316.722:39(=161):94(477.87:4-191.2)

\title{
ХАРАКТЕРИСТИКА СУСПІЛЬНО-КУЛЬТУРНОГО СЕРЕДОВИЩА ЕТНІЧНИХ ГРУП (РУСИНІВ, ЛЕМКІВ TA РУСНАКІВ) В ІСТОРИЧНОМУ КОНТЕКСТІ
}

\section{- абрика-Процька Ольга Романівна}

Кандидат мистецтвознавства, доцент,

ORCID: 0000-0001-5188-1491, olgafp4@ukr.net,

Прикарпатський національний університет імені Василя Стефраника, вул. Шевченка, 57, Івано-Франківськ, Україна, 76000

\section{- Для цитування:}

Фабрика-Процька, О.Р. (2019). Характеристика суспільно-культурного середовища етнічних груп (русинів, лемків та руснаків) в історичному контексті. Питання культурології, (35), 226-237. doi: https://doi.org/10.31866/2410-1311.35.2019.188820.

\section{- Анотація}

Метою статті $€$ висвітлення суспільно-культурного середовища русинів, лемків та руснаків в історичному контексті. У дослідженні використано методи аналізу історичних джерел, що відображають основні тенденції розвитку та функціонування суспільнокультурного життя етнічних груп українців. Соціокультурний метод дозволив розглянути русинську, руснацьку та лемківську культуру як складову частину національних традицій українського народу крізь призму детермінуючого фактора культури. Для одержання всебічної інформації щодо висвітлення загальної характеристики суспільно-культурного життя етнічних груп було використано ряд теоретичних методів: оглядово-аналітичний аналіз наукової, фольклористичної, історичної, етнографрічної, культурологічної та мистецтвознавчої літератури в межах досліджуваної тематики; історичний метод, завдяки якому прослідковано історичні етапи руснаків, русинів та лемків; а також френоменологічний метод для осмислення вагомості культури етнічних груп українців у контексті культуротворчих проявів ідентифрікації. Наукова новизна роботи полягає у комплексному висвітленні суспільно-культурного середовища в контексті історії. Висновки. Отже, східнослов'янська група Карпатського регіону, зокрема України, яку становлять закарпатські русини-українці та русини Сербії, протягом століть зазнавала впливу тих народів, які ії оточували (поляків, словаків, угорців, румунів, німців, сербів, хорватів), однак вони також збагачували культуру цих народів, зокрема, Бачки, Керестура та інших місць. Та, незважаючи на такі обставини, у своїй основі русини-переселенці та українціпереселенці не втратили своєї національної ідентифікації. Культурні зв'язки між русинами Бачки та населенням Карпат ніколи не переривалися. Можемо говорити про єдність лемків і руснаків Бачки у національній свідомості, культурі та мові, їх взаємодію у культурній та етнічній площині усіх русько-лемківських діаспор ще на початку XIX століття, перед 
проголошенням політизації лемківського та русинського питання. Свідченням спорідненості руснаків Бачки з усім русько-українським етнокультурним простором $є$ поширення жанру коломийки, традицію ж шкільництва русини принесли з собою до Бачки із Закарпаття. Тож можемо стверджувати про спорідненість українського етносу на території Сербії і Хорватії. Проте русинська ідентичність може зміцнюватися лише тоді, коли буде орієнтуватися на українську націю. Доведено, що вивчення історії, особливостей визначення ідентифікації українського населення на різних теренах $€$ одним із головних питань сьогодення. Народна культура етнічних груп русинів, лемків та руснаків має ознаки загальноукраїнської культури. Незважаючи на складні історичні події, у своїй основі лемки, русини та руснаки-переселенці зберегли свою національну, зокрема українську, специфіку ідентифікації.

Ключові слова: історія; суспільно-культурна діяльність; руснаки; русини; лемки; українці; національна ідентичність

\section{Вступ}

У незвичних реаліях сьогодення особливої потреби набувають питання консолідації українського етносу як у країні, так і за ії межами. Розпорошені по всьому світу українці пройшли складні шляхи розвитку на територіях багатьох держав. Однак, незважаючи на процеси інтеграції у різні суспільства, зберегли характерні особливості своєї культури та мови.

Вивчення та аналіз процесів розвитку духовної культури, зокрема, суспільнокультурного середовища русинів, руснаків та лемків як невід'ємної складової частини загальнонаціональної культури України, - актуальне завдання мистецтвознавства та культурології у наш час.

Зацікавленість русинами бере початок із кінця XIX - початку XX ст. Велику роботу в національному та культурному визначенні ідентифікації русинів Бачки (паннонські русини, які проживають у Сербії і Хорватії. - Aвт.) здійснювало чимало дослідників, про це написано багато публіцистичних та наукових праць.

Насамперед відзначимо чисельні роботи всесвітньовідомого українського фольклориста та етнографра Володимира Гнатюка. Його зацікавленість українським фольклором виникла під впливом М. Грушевського, О. Колесси, І. Франка, М. Драгоманова. Він упродовж 1895-1903 рр. здійснив шість фольклорно-етнографічних експедицій на Закарпаття при написанні книги «Етнографични материяли з Угорскей Руси», яка містить велику кількість фактологічних матеріалів і $€$ вагомим джерелом для подальшого вивчення минулого русинів Угорщини та колишньої Югославії, а також для пізнання мови та фольклору Закарпаття. Учений стверджував, що русини Південної Угорщини належать до українського народу, хоча їхня мова зазнала великого впливу з боку словацької (Гнатюк, 1985-1988).

У другій половині XX ст. фольклорист та українознавець М. Мушинка (1989), досліджуючи наукову діяльність Володимира Гнатюка, виявив велику кількість документів та фотографій, які забезпечили створення музею видатного вченогофольклориста в його рідному селі Велесневі на Тернопільщині. Він став одним із організаторів з"їзду славістів-україністів у Празі, хоча члени делегації УРСР 
відмовилися підтримати пропозицію про створення Міжнародної асоціації україністів. Основну увагу у своїй науковій діяльності М. Мушинка присвятив фольклорно-етнографрічній спадщині Пряшівщини та й загалом національній культурі Карпат і Балкан.

Вагомий внесок у дослідження українських етнічних меншин вніс засновник та перший голова Союзу росіян і українців Югославії Ю. Тамаш $(1997 ; 2016)$, який займався російською, українською, воєводинською та югославською поезією XX століття, історією російської літератури, а також історією та культурою населення Карпат і руснаками Бачки як етнічною частиною українського народу. Досліджуючи світогляд русинів Південної Угорщини крізь призму апокрифрів з їх рукописних збірників із XVIII та XIX ст., А. Дуличенко (1972) звернув увагу, що у середині XIX ст. русинська інтелігенція почала налагоджувати зв'язки з русинськими громадськими і культурно-освітніми діячами у межах Австрійскої імперії, та на початку 1850-х рр. у газеті «Вестникъ для русиновъ» русини з Бачки публікують перші відомості про себе. Також доробок М. Жирош (2008), О. Тимко (1994), О. Румянцева (2008) розкриває історію, життя та побут русинів, наголошуючи, що, незважаючи на доволі високий рівень економічного розвитку русинів Бачки, їхнє культурно-освітнє життя було менш розвинутим, ніж українців Галичини.

Однак культурне середовище русинів, лемків та руснаків Сербії та Хорватії недостатньо висвітлене та потребує окремого дослідження.

\section{- Мета статті}

Метою статті є висвітлення суспільно-культурного середовища русинів, лемків та руснаків в історичному контексті.

Методологія дослідження полягає у поєднанні методів пізнання, зумовлених вимогами об'єктивного аналізу історичних джерел, що відображають основні тенденції розвитку та ффункціонування суспільно-культурного життя етнічних груп українців. Використання соціокультурної методології дозволило розглянути об'єкт - русинську, руснацьку та лемківську культуру як складову частину національних традицій українського народу крізь призму детермінуючого фрактора культури. Соціокультурний підхід акцентує увагу на єдності культури й суспільства з опорою на теоретичні положення культурології, психології, соціології, етнографрії тощо. Для одержання всебічної інформації щодо висвітлення загальної характеристики суспільно-культурного життя етнічних груп було використано ряд теоретичних методів: оглядово-аналітичний аналіз наукової, фольклористичної, історичної, етнографічної, культурологічної та мистецтвознавчої літератури в межах досліджуваної тематики, історичний метод, завдяки якому прослідковано історичні етапи становлення руснаків, русинів та лемків, а також френоменологічний метод для осмислення вагомості культури етнічних груп українців у контексті культуротворчих проявів ідентифікації.

\section{- Виклад матеріалу дослідження}

До східнослов'янської групи Карпатського регіону, зокрема України, належать закарпатські русини-українці та русини Сербії. Протягом століть бездер- 
жавності України їх мова та культура зазнавали впливу тих народів, які їх оточували, а саме: поляків, словаків, угорців, румунів, німців. Однак вони також збагачували культуру цих народів. Після переселення до Бачки, Керестура та інших місць українці й русини взаємодіяли з хорватами, сербами, німцями. Але і в таких обставинах у своїй основі русини-переселенці та українці-переселенці не втратили національної ідентифікації.

Незважаючи на сьогоденне розселення у Польщі, Чехії, Словаччині, Угорщині, Румунії, Хорватії, Сербії, русини, лемки та руснаки продовжують підтримувати зв'язки з Україною, вважаючи ії̈ своєю батьківщиною. Особливо це стосується бачвансько-сримських русинів, які понад 260 років тому переселились на сучасну територію Сербії з Шариського та Земплинського регіонів Словаччини і спільно протягом кількох століть входили до Закарпаття й були одним цілим з усім українським народом (Хланта, 2014).

Початково русини населяли територію Східної Словаччини, а саме: регіони Горніци, Шариш, Земплин, Спиш, а також частково - польську Лемківщину, західну Галичину та сучасну Закарпатську область. Втікаючи від лиха, утисків та переслідувань, протестуючи проти гноблення і закріпачення, у пошуках кращого життя русини в середині XVIII ст. почали переселятися до південних частин колишньої Угорщини - на вільні простори Бачки.

Перші групи поселенців приїхали у 1745 р. в Керестуру на основі урядового контракту, який був виданий мешканцю села Червеньова Берегського комітату (Мукачівського району Закарпатської області). Документ передбачав дозвіл привести з собою 200 русинів греко-католицького віросповідання (Хланта, 2014). Згодом оселялися у Коцурі та інших місцях Сербії. Поселяючись на незайманих або спустошених війнами землях, привозили із собою звичаї, рідну мову, обряди, промисли, народну творчість та віру. Найбільша частина русинів із Закарпаття оселилася на території Бачки, до якої раніше прибуло чимало переселенців із Галичини. «Протестуючи проти панщини та експлуатації, селяни з польської території, тобто з Галичини, втікали до Закарпаття на угорську територію... Про це свідчать звіти жупанатських комісій, що вже у XVI ст. у жупанатах Спиш, Шариш, Земплин, Унг, Берег, Мараморош, тобто від Тренчина по Сигет, зустрічаються тисячі прізвищ утікачів із Галичини та Закарпаття. Від панщини втікали і в наступні століття...» (Хланта, 2014, с. 4).

Дослідник О. Тимко (1994), вивчаючи життя русинів Карпат, які тривалий час добиралися до Бачки, у християнському календарі «Дзвони» констатує: «...Де були пани жорстокі, важкі умови для життя, вони їх покидали і вирушали далі. Котрі проходили через угорський та словацький край, ті вбирали до своєї мови чимало їхніх слів. Були групи, які мали по 60-70 \% угорської термінології. Групи, котрі проходили через Румунію до Бачки, ті мало запозичили чужого. Потім вони злилися до одного, в якому переважала угорська термінологія. У ті часи то було цілком закономірне і природнє явище, то був жаргон, який давав можливість порозумітися із сусідами, зокрема угорцями» (с. 149-150). Згодом із м. Керестура переселялися до м. Нові Сад.

Духовна культура русинів та лемків, зокрема усна, є свідченням єдності бойків, лемків та гуцулів із південнослов'янським світом та русинством як частиною 
української нації. Лемки, які жили по обох схилах Карпат, переймали впливи поляків, словаків та угорців. Відзначимо музичний (танцювальний) фоольклор жанр коломийки. У XX ст. у весільному обряді лемків коломийку було замінено чардашем. Проте зберігся давній танок «обертас» або «обертак».

Щодо малювання ікон, то, зокрема, лемківською особливістю $є$ малювання образів на склі з апокрифічними мотивами. Живопис на склі у Карпатах був поширеним упродовж XIX століття і розповсюджувався не стільки у церквах, скільки у селянських домівках (хижах). Особливо популярними були на образах святі: Миколай, Ілля, Павло, Петро, Георгій, а найбільше - Богородиця з Ісусом, так звана Лемківська Мадонна.

Зокрема, Володимир Гнатюк лемківську говірку вважав IV числом групи українських верховинських або карпатських говірок, яка «поширюється на південнозахідну частину Буковини і гірську частину Галичини, аж до Попраду і на Угорську Русь, та поділяється на наступні говірки:

- чисто українська говірка, якою розмовляють гуцули і бойки на Буковині, Галичині і в Угорщині;

- мішана говірка, головна характеристика якої - нерухомий наголос на попередньому складі, а розмовляють нею лемки Галичини і Угорщини;

- словацько-українська, сильно пословачена говірка, якою розмовляють лише в Угорщині, частині жуп (регіонів) Земплин, Шариш, Спиш, Абауй, а також колоністи у Бачці і Чриму (Славонії)» (Сополига, 2016, с. 235).

Так, Ю. Тамаш (1997) визначав мову русинів Бачки наближеною до лемківських говорів та східнословацького діалекту (віходнярська говірка). На його думку, одна діаспора не може бути материком другій діаспорі, бо найчастіше діаспори «...змушені шукати своє коріння між материнськими націями (наприклад, лемки та русини між українцями) до тих пір, доки сама діаспора не стане сама собі матір'ю, як це сталося в руснаків Бачки» (с. 235). У зв'язку з цим слід констатувати, що східнословацький діалект, а точніше - віходнярська говірка, мова русинів Бачки та лемківський діалект, мають спільну основу консервативної збереженої мовної системи.

Юліан Тамаш (2016) зазначає, що на початку XIX століття, перед проголошенням політизації лемківського та русинського питань, існувало чимало неспростованих фрактів, які у царині національної свідомості, культури та мови засвідчують єдність лемків і руснаків Бачки, створюючи взаємодію у культурній та етнічній площині усіх русько-лемківських діаспор, незважаючи на політичноісторичні труднощі, що спіткали їх у XX столітті.

До 1918 року русини-українці Галичини та русини-українці, розселені на території Сриму, Бачки, Славонії та Боснії, жили в одній державі - АвстроУгорській імперії. Однак 31 жовтня 1918 р. Австро-Угорська імперія розпалася. За Сен-Жерменським договором 10 вересня 1919 р. Буковина відійшла до Румунії, а Закарпаття - до Чехословаччини, Галичина ж опинилася у складі Польщі.

Дослідник І. Хланта (2014) зазначає, що «...на просторах південнослов'янських земель 1 грудня 1918 р. було сформовано нову державу - Королівство сербів, хорватів і словенців (із жовтня 1929 р. - Югославія), до складу якої увійшли Сербія, в т. ч. Вардарська Македонія, Чорногорія, а також південно- 
слов'янські землі колишньої Австро-Угорщини - Боснія, Герцеговина, Хорватія, Словенія, Воєводина, Македонія і Славонія» (с. 6).

За висловом І. Хланти (2014), з виникненням міграційних процесів від середини XVIII ст. з північно-східних районів Угорщини (Абауй, Боршод, Земплин, Спіш, Унг, Угоч, Берег та Мараморош) русини прийшли на територію сучасної Воєводини (Сербії). У першій хвилі оселилися у Керестурі та Коцурі, згодом із Бачки емігрували малими групами до Славонії та Сриму. Велика кількість поселенців прибула з Шарисько-Земплинського району Словаччини, говірка яких і лягла в основу сучасної стандартної літературної мови русинів колишньої Югославії. Із того часу русини-українці Бачки, Славонії, Сриму та Боснії живуть відокремлено від північно-східних русинів-українців.

Переселяючись на нові місця, русини переносили і свої традиції. Так, традицію шкільництва до Бачки вони перенесли із Закарпаття. Зокрема, у народній школі навчали писати, читати, рахувати, церковного співу, виховували віру та ін.

Після розпаду Австро-Угорської імперії, відчуваючи потребу плекання рідної мови та культури, у Новому Саді русини в 1919 р. створили перші культурно-освітні товариства, а у 1922 р. українцями-переселенцями було створено товариство «Просвіта» у Загребі (Боснія). При цій організації розпочали свою діяльність читальні, драматичні, танцювальні, музичні та літературні гуртки, жінки отримували знання про господарство, дівчата навчалися вишивати та ін. Організації були копією культурно-освітнього товариства «Просвіта» (заснованого у Львові 1868 р.) і давали можливість русинам легше адаптуватися до місцевого культурного оточення, а згодом для їх нащадків стали необхідністю щодо збереження національної та культурної ідентичності. Така ж культурна діяльність розвивалась при школах та парафріях. Виходили друком «Руски календар» (1921), щотижнева газета «Руски новини» (1924-1941рр.), підручники для школярів та ін.

У 1935 р. у Шиді було створено організацію під назвою «Союз українських школярок у Югославії», метою якої було виховання у патріотичному українському та югославському дусі.

1945 р. у Руському Керестурі побачила світ газета «Руске слово», а з 1964 р. при ній почав друкуватись додаток «Літературне слово».

Разом із тим, русини та українці Хорватії не мали організованої середньої школи, але у них була можливість вивчати програму середньої школи у т. зв. Літніх школах для русинів і українців, які організовувалися після закінчення навчального року у літні місяці. А починаючи із 1968 року, на філософському факультеті Університету Загреба уже викладалася українська мова і література. Того ж року було створено «Союз русинів і українців Хорватії» - організацію, яка нараховувала понад 600 членів та ґрунтувалася на об'єднанні русинів і українців, при чому обидві групи вважали Україну своєю прабатьківщиною.

Починаючи з 1971 р., у Загребі русинською, українською та хорватською мовами виходив у світ інфрормативний часопис «Нова думка». Згодом почав видаватися часопис для школярів «Венчик» як навчальне доповнення для школярів та вчителів в дусі любові до рідної мови та культури.

Однак культурно-просвітницька діяльність русинів та українців не завжди мали сприятливі умови в Югославії. Наприклад, заборонялося мати офіційні 
контакти з культурними осередками України, навчати молодь мови, музики, культури, танцям, фрольклору, отримувати кадрову та іншу допомогу. За висловом дослідників, місцеве населення могло спиратися лише на свої сили у Воєводині або у Хорватії.

Серед діючих організацій, куди залучалися як представники хорватського народу, так і інших національних меншин, назвемо Угрупування україністів, Товариство хорватсько-української співпраці та Хорватсько-українське товариство. Щороку русини та українці Хорватії організовували різноманітні культурні заходи. Серед фольклорних фестивалів відомими стали: «Петровецький дзвін» (Петровці); «Міклушевецьке літо» (Міклушевці); огляди співочих колективів і хорів «Дравські хвилі» (Осієк); фестиваль дитячої творчості «Славонський Брод»; дні української і русинської культури (Рієц, Загреб); Шевченківські вечори (Загреб, Липовляни, Каніж); поетичні вечори, присвячені творчості письменників з України і місцевої діаспори (Хорватія, Воєводина - Сербія і Боснія); вечори пісні, танцю і фольклору (Шумеч, Каніж, Липовляни) та ін.

У 1985 році при міській бібліотеці Загреба почала діяти Головна бібліотека русинів і українців, роботу якої фрінансує Міністерство культури Республіки Хорватія.

Після проголошення незалежності Хорватії в Університеті Загреба на фрілософрському фракультеті з 2001 року існує кафредра української мови та літератури. У русинів $€$ свої веб-сторінки, а також вони мають право на інформативну і видавничу діяльність, друк книг (періодичні видання «Нова думка», «Віночок», «Наша газета», «Вісник», «Думки з Дунаю»). Відповідно до існуючого Закону про права національних меншин етнічні групи українців мають право на культурну автономію, політичне представництво у Хорватському Парламенті і у Раді національних меншин уряду Республіки Хорватія, вибирають і пропонують своїх представників, окремо для русинської і окремо для української меншин. На рівні структур місцевого і регіонального управління і самоуправління мають право засновувати свої Ради і вибирати представників русинської і української національних меншин, засновувати свої координації; мають права на освіту мовою меншини та на службове використання своєї мови і письма, на двомовність, тобто можливість використовувати власні топоніми назви сіл і вулиць, як і свою національну символіку: гімн, прапор та ін.

У Загребі 2002 року було засновано Товариство української культури. Серед основних засад діяльності організації - представлення і популяризація української культури між русинами і українцями Хорватії.

У Славонії (частина Хорватії) у 2005 році було засновано третю організацію «Руснак», яка об'єднує також порівняно невелику кількість представників виключно русинської національної меншини та пропагує думку, що Україна не є прабатьківщиною русинів.

Через суперечки та бажання окремих осіб здійснювати власну політику культурного розвитку української національної меншини у Хорватії з «Союзу русинів і українців Хорватії» відокремились українці та у 2008 році утворили 4 українських культурно-мистецьких та просвітних товариства, які сформувались в «Українську громаду Республіки Хорватія». 
Свідченням спорідненості руснаків Бачки з усім українським етнокультурним простором $є$ поширення жанру коломийки. «Коломийка - одночасно мікроі макроструктура, i iї можна кваліфікувати як короткий вірш найрізноманітнішого змісту», - зазначає дослідник Ю. Тамаш (2016, с. 236). Це не простий вірш жартівливого змісту, який бере початок із XVI століття. Такі ліричні поетичні тексти зустрічаються лише в українців та руснаків. Вони не притаманні ані полякам, ані словакам. Трапляється запозичення текстів від русинів-українців, але з іншою формою та метроритмом. Схожі поетичні фрорми мають інші народи: поляки - краков'як, серби - бетярець, росіяни - частушки, французи - куплет, однак в усіх них різний метроритм.

Культурні зв'язки між русинами Бачки та населенням Карпат ніколи не переривалися. Слушну думку висловив дослідник Ю. Тамаш (2016) про те, що русинська регіональна ідентичність може зміцнюватися лише тоді, коли буде спиратися на свою історичну українську націю, а також на збереження глибокого зв'язку людини і території, його зв'язку з часом і простором, комплексом історичної та просторової дійсності, збереженням регіональної мовної самобутності тощо. «Щоб русинство залишилось живим із природною мовою, воно мусить обмежитися регіональною культурною ідентичністю у рамках українського культурно-історичного простору. Новітня карпаторусинська ідея, - за словами Ю. Тамаша (2016), - та практика ії реалізації, на жаль, набула не культурного, а суто політичного спрямування як різновид антиукраїнської, а отже, і антирусинської діяльності» (с. 237).

\section{- Висновки}

Отже, східнослов'янська група Карпатського регіону, зокрема України, яку становлять закарпатські русини-українці та русини Сербії, протягом століть зазнавала впливу тих народів, які її оточували (поляків, словаків, угорців, румунів, німців, сербів, хорватів), однак і вони також збагачували культуру цих народів, зокрема Бачки, Керестура та інших місць. Та, незважаючи на такі обставини, у своїй основі русини-переселенці та українці-переселенці не втратили своєї національної ідентифікації.

Культурні зв'язки між русинами Бачки та населенням Карпат ніколи не переривалися. Можемо говорити про єдність лемків і руснаків Бачки у національній свідомості, культурі та мові, їх взаємодію у культурній та етнічній площині усіх русько-лемківських діаспор ще на початку XIX століття, перед проголошенням політизації лемківського та русинського питання.

Свідченням спорідненості руснаків Бачки з усім русько-українським етнокультурним простором $€$ поширення жанру коломийки, традицію шкільництва русини також принесли з собою до Бачки із Закарпаття. Тож можемо стверджувати щодо єдності українського етносу на території Сербії і Хорватії. Проте русинська ідентичність може зміцнюватися лише тоді, коли буде спиратися на українську націю.

Таким чином, національна приналежність та нація загалом визначаються тільки як суб'єктивне право людини на вибір ідентичності, а не як колективна сутність, сфрормована культурою, історією та суспільним життям. Мовний, лі- 
тературний, культурний, політичний, національний регіоналізми мають сенс та позитивний характер лише тоді, коли вирішують існуючі історичні, суспільні та психологічні проблеми.

\section{- Список використаних джерел}

Гнатюк, В. (1985-1988). Етнографрични материяли з Угорскей Руси (Т. 1-5). Нови Сад: Руске слово.

Дуличенко, А. (1972). О єдним жридлє у вязи историї югославянских Руснакох у XVIII и XIX вику. Шветлоси, 2, 162.

Жирош, М. (2008). Бачванско-Сримски руснаци дома и у Швеце 1745-2005 (Т. 7). Нови Сад: Руске Слово.

Карась, Г.В. (2012) Музична культура української діаспори у світовому часопросторі XX століття [Монографія]. Івано-Франківськ: Тіповіт.

Мушинка, М. (1989). Глас коцурского Русина сторочней давносци. Нова думка, 78, рок XVIII, 22-25.

Рамач, Я. (2007). Руснаци у Южней Угорскей (1751-1918). Нови Сад: Войводянска академия наукох и уметносцох.

Румянцев, О. (2008). Галичина - Боснія - Воєводина: українські переселенці з Галичини на території югославських народів в 1890-1990рр. Київ: ФАДА, ЛТД.

Сополига, М. (Ред.). (2016). Науковий збірник Музею української культури у Свиднику = Vedecky zbornik Muzea ukrajinskej kultury vo Svidniku (Вип. 28: Українці в історії та культурі Карпат). Свидник.

Тамаш, Ю. (1997). История рускей литератури. Београд: Завод за Уџбенике.

Тамаш, Ю. (2016). Чому русини/руснаки Бачки частина українського народу. В Науковий збірник Музею української культури у Свиднику = Vedecky zbornik Muzea ukrajinskej kultury vo Svidniku (Вип. 28: Українці в історії та культурі Карпат, c. 228-240). Свидник.

Тимко, О. (1994). Шлїди историї у нашей писнї. В Християнски календар "Дзвони" за 1995 рок (с. 149-150). Нови Сад.

Хланта, І.В. (Упоряд.). (2014). Пісня над Дунаєм. Народні пісні русинів (українців) Сербії. Ужгород: Патент.

\section{- References}

Dulichenko, A. (1972). O yednym zhrydlie u viazy ystoryi yuhoslavianskykh Rusnakokh u XVIII y XIX vyku [On the history of the Yugoslavian Rusnaks in the eighteenth and nineteenth centuries], Shvetlostc, 2, 162 [in Serbian].

Girosh, M. (2008). Bachvansko-Srimski rusnatci doma i u Shvetce 1745-2005. [BachvanSrim Rusnaks at Home and in Sweden 1745-2005] (Vol. 7). Novi Sad: Ruske Slovo [in Serbian].

Hnatiuk, V. (1985-1989). Etnohrafychny materyialy z Uhorskei Rusy [Ethnographic materials from the Hungarian Rus] (Vol. 1-5). Novy Sad: Ruske Slovo [in Serbian].

Karas, G. (2012). Muzychna kultura ukrainskoi diaspory u svitovomu chasoprostori XX stolittia [Musical culture of the Ukrainian diaspora in the world time period of the twentieth century] [Monograph]. Ivano-Frankivsk: Tipovit [in Ukrainian]. 
Khlanta, I. (Comp.). (2014). Pisnya nad Dunayem. Narodni pisni rusyniv (ukrayintsiv) Serbiyi [Song over the Danube. Folk songs of Ruthenians (Ukrainians) of Serbia]. Uzhgorod: Patent [in Ukrainian].

Mushynka, M. (1989). Glas kocurskogo Rusina storochnei davnosci [Voice of the Kokur Rusin a century ago]. Nova dumka, 78, rok XVIII, 22-25 [in Serbian].

Ramach, Y. (2007). Rusnatsi Yuzhney Ugorske (1751-1918) [The Rusnaks of South Hungary (1751-1918)]. Novi Sad: Voivodianska akademiia naukokh i umetnostcokh [in Serbian].

Rumyantsev, O. (2008). Halychyna - Bosniia - Voievodyna: ukrainski pereselentsi z Halychyny na terytorii yuhoslavskykh narodiv v 1890-1990 rr. [Galicia - Bosnia - Vojvodina: Ukrainian immigrants from Galicia in the territory of the Yugoslavian peoples in 1890 1990]. Kyiv, FADA, LTD [in Ukrainian].

Sopolyha, M. (Ed.). (2016). Vedecky zbornik Muzea ukrajinskej kultury vo Svidniku [Scientific collection of the Museum of Ukrainian Culture in Svydnyk] (Issue 28: Ukraintsi v istorii ta kulturi Karpat [Ukrainians in the history and culture of the Carpathians]). Svydnyk [in Ukrainian].

Tamash, Y. (1997). Istoriya russkoy literatury [History of Russian Literature]. Belgrade: Zavod za Uџbenike [in Serbian].

Tamash, Y. (2016). Chomu rusyny/rusnaky Bachky chastyna ukrainskoho narodu [Why Ruthenians / Russians Bachki are part of the Ukrainian people]. In Vedecky zbornik Muzea ukrajinskej kultury vo Svidniku [Scientific collection of the Museum of Ukrainian Culture in Svydnyk] (Issue 28: Ukraintsi v istorii ta kulturi Karpat [Ukrainians in the history and culture of the Carpathians]). Svydnyk [in Ukrainian].

Timko, O. (1994). Shlyidy ystoryyi u nashey pysnyi [Follow the history in our publications]. In Khrystyiansky kalendar "Dzvony" za 1995 rok (p. 149-150). Novy Sad [in Serbia].

\section{- CHARACTERISTICS OF SOCIO-CULTURAL ENVIRONMENT OF ETHNIC GROUPS (RUTHENIANS, LEMKOS, AND RUSNAKS) IN HISTORICAL CONTEXT}

\section{- Olha Fabryka-Protska}

- PhD in Art Studies, Associate Professor,

ORCID: 0000-0001-5188-1491, e-mail: olgafp4@ukr.net,

Vasyl Stefanyk Precarpathian National University,

Ivano-Frankivsk, Ukraine

\section{- Abstract}

The purpose of the article is to cover the socio-cultural environment of Ruthenians, Lemkos and Rusnaks in a historical context. The study used methods of analysis of historical sources, which reflect the main trends in the development and functioning of the socio-cultural life of ethnic groups of Ukrainians. The sociocultural method made it possible to consider the Ruthenian, Rusnak and Lemko culture as an integral part of the national traditions of the Ukrainian people through the 
prism of the determining factor of culture. To obtain comprehensive information on the coverage of the general characteristics of socio-cultural life of ethnic groups, a number of theoretical methods were used: review and analytical analysis of scientific, folklore, historical, ethnographic, cultural and art literature within the studied topics; a historical method that traces the historical stages of Ruthenians, Rusnaks, and Lemkos, as well as a phenomenological method for understanding the importance of the culture of ethnic groups of Ukrainians in the context of cultural aspect of identification. The scientific novelty of the work lies in the comprehensive coverage of the sociocultural environment in the context of history. Conclusions. Therefore, the Eastern Slavic group of the Carpathian region, in particular Ukraine, made up of Transcarpathian Rusyn-Ukrainians and Rusyns of Serbia, for centuries was influenced by those peoples who surrounded them (Poles, Slovaks, Hungarians, Romanians, Germans, Serbs, Croats), they also enriched the culture of these peoples, including Bachka, Kerestur and other places. But despite these circumstances, the Ruthenian and Ukrainian migrants did not lose their national identity. Cultural ties between the Bachka Ruthenians and the Carpathian population have never been broken. At the beginning of the $19^{\text {th }}$ century, before the politicization of the Lemko and Ruthenian issues, we could talk about the unity of the Lemkos and the Bachka Ruthenians in the realm of national consciousness, culture and language, their interaction in the cultural and ethnic plane of all Rusyn-Lemko diasporas. Evidence of the affinity of the Bachka Ruthenians with the entire Rusyn-Ukrainian ethnocultural space is the spread of the genre of Kolomyia, and they brought the tradition of the Ruthenian school to Bachka from Transcarpathia. Therefore, we can claim that Ukrainian ethnicity is related to Serbia and Croatia. However, Ruthenian identity can only be strengthened when it focuses on the Ukrainian nation. It is proved that studying the history, peculiarities of determining the identification of the Ukrainian population in different territories is one of the main issues of today. The folk culture of ethnic groups of Ruthenians, Lemkos and Rusnaks bears the marks of Ukrainian-wide culture. Despite the complex historical events, the Lemkos, Ruthenians and Rusnaks migrants, at their core, retained their national, in particular, Ukrainian specificity of identification.

Keywords: history; social and cultural activities; Ruthenians; Rusnaks; Lemkos; Ukrainians; national identity

\section{ХАРАКТЕРИСТИКА ОБЩЕСТВЕННО-КУЛЬТУРНОЙ СРЕДЫ ЭТНИЧЕСКИХ ГРУПП (РУСИНОВ, ЛЕМКОВ И РУСНАКОВ) В ИСТОРИЧЕСКОМ КОНТЕКСТЕ}

\section{- Фабрика-Процкая Ольга Романовна}

Кандидат искусствоведения, доцент, ORCID: 0000-0001-5188-149, e-mail: olgafp4@ukr.net, Прикарпатский национальный университет имени Василия Стефраника, Ивано-Франковск, Украина

\section{- Аннотация}

Целью статьи является освещение общественно-культурной среды русинов, лемков и руснаков в историческом контексте. В исследовании использованы методы анализа 


\section{CULTURAL AND SOCIAL ACTIVITY}

Issues in Cultural Studies

исторических источников, отражающих основные тенденции развития и функционирования общественно-культурной жизни этнических групп украинцев. Социокультурный метод позволил рассмотреть русинскую, руснацкую и лемковскую культуру как составную часть национальных традиций украинского народа через призму детерминирующего фрактора культуры. Для получения всесторонней информации по освещению общей характеристики общественно-культурной жизни этнических групп был использован ряд теоретических методов: обзорно-аналитический анализ научной, фольклористической, исторической, этнографической, культурологической и искусствоведческой литературы в пределах исследуемой тематики; исторический метод, благодаря которому прослежены исторические этапы руснаков, русинов и лемков; а также феноменологический метод для осмысления значимости культуры этнических групп украинцев в контексте культурных проявлений идентификации. Научная новизна работы заключается в комплексном освещении общественно-культурной среды в контексте истории. Выводы. Итак, восточнославянская группа Карпатского региона, в частности Украины, которую составляют закарпатские русины-украинцы и русины Сербии, на протяжении веков подвергалась воздействию окружающих народов (поляков, словаков, венгров, румын, немцев, сербов, хорватов), однако они также обогащали культуру этих народов, в частности, Бачки, Керестур и других мест. Но, несмотря на такие обстоятельства, в своей основе русины-переселенцы и украинцыпереселенцы не потеряли своей национальной идентификации. Культурные связи между русинами Бачки и населением Карпат никогда не прерывались. Можем говорить о единстве лемков и руснаков Бачки в национальном сознании, культуре и языке, их взаимодействии в культурной и этнической плоскости всех русско-лемковских диаспор еще в начале XIX века, перед провозглашением политизации лемкивского и русинского вопроса. Свидетельством родства руснаков Бачки со всем русско-украинским этнокультурным пространством является распространение жанра коломыйки, традицию школ русины тоже принесли с собой в Бачки из Закарпатья. Поэтому можно утверждать о родстве украинского этноса на территории Сербии и Хорватии. Однако русинская идентичность может укрепляться только тогда, когда будет ориентироваться на украинскую нацию. Доказано, что изучение истории, особенностей определения идентификации украинского населения в различных аспектах является одним из главных вопросов современности. Народная культура этнических групп русинов, лемков и руснаков имеет признаки всеукраинской культуры. Несмотря на сложные исторические события, в своей основе лемки, русины и руснаки-переселенцы сохранили свою национальную, в частности украинскую, специфику идентификации.

Ключевые слова: история; общественно-культурная деятельность; руснаки; русины; лемки; украинцы; национальная идентичность 